\title{
Nilai kearifan lokal pada lagu Lampung
}

\author{
Windo Dicky Irawan', Yasinta Mahendra², Junaidi3 \\ 1,2,3 Universitas Muhammadiyah Kotabumi \\ Correspondence: abubilqis9o@gmail.com
}

\begin{abstract}
Local wisdom is a value that is a role model for the people of Lampung. These values are used as guidelines and a way of life for the people of Lampung. In addition, values are also things that must be pursued in order to have a better life. Therefore, cultural experts place the highest cultural value. The values of local wisdom in the people of Lampung are called piil pesenggiri which consists of meeting nyimah, nengah nyappur, sakai sambaian, and nickname adek. These values are implied in all aspects of life, including the popular Lampung songs. This article aims to describe the local wisdom values of the Lampung area in popular Lampung songs.
\end{abstract}

Keywords: Local Wisdom, Pïl Pesenggiri, Lampung.

\section{Pendahuluan}

"Kearifan lokal berdasarkan kamus Inggris-Indonesia, terdiri atas dua kata yaitu kearifan (wisdom) dan lokal (local). Local berarti setempat (Halim, 2003:109)". Maksudnya ialah hanya dalam cakupan daerah saja. "Sementara wisdom sama dengan kebijaksanaan (Halim, 2003:210)". "Faktanya, kearifan lokal (local wisdom) merupakan sebagai gagasangagasan, nilai-nilai, pandangan-pandangan setempat (lokal) yang bersifat penuh bijaksana atau kearifan, bernilai baik, yang tertanam dan diikuti oleh anggota masyarakatnya (Ningsih, D.R \& Irawan, W.D., 2018:59-67)”.

Secara filosofis Fachrudin (2009:4) mengatakan bahwa "kearifan lokal dapat diartikan sebagai sistem pengetahuan masyarakat lokal atau pribumi (indigenous knowledge systems) yang bersifat empirik dan pragmatis. Bersifat empirik karena hasil olahan masyarakat secara lokal berangkat dari fakta-fakta yang terjadi di sekeliling kehidupan mereka. Bertujuan pragmatis karena seluruh konsep yang terbangun sebagai hasil olah pikir dalam sistem pengetahuan itu bertujuan untuk pemecahan masalah sehari-hari (daily problem solving)".

Kearifan lokal secara tegas diidentifikasikan dengan budaya terdekat dan mencerminkan gaya hidup dari area lokal tertentu (area lokal terdekat). Di Indonesia, istilah budaya sekitar sering dibandingkan dengan budaya etnis atau sub-etnis. Salah satu komponen budaya yang berfungsi 
sebagai pendukung kebudayaan adalah kesenian, dan seni sastra merupakan salah satu bagian dari sebuah seni yang dapat diterapkan dalam komponen lagu-lagu.

Di dalam lagu tentunya terdapat teks lagu yang disebut lirik. Pengertian dari lirik atau syair lagu dapat dianggap sebagai sebuah puisi, dan juga sebaliknya. Hal demikian juga dikatakan oleh Luxemburg (1989:35) yaitu "definisi mengenai teks puisi bukan hanya mencakup jenis-jenis sastra melainkan juga syair-syair lagu pop”. Syair-syair lagu pop tersebut terdapat berbagai makna, seperti makna kearifan lokal, dsb.

Penelitian suatu kearifan lokal nilai-nilai budaya Lampung (piil pesenggiri) dalam kumpulan lagu-lagu Lampung populer dapat melestarikan budaya daerah yang hampir punah, sebagaimana masyarakat Lampung (khususnya generasi muda) yang sudah hampir tidak lagi mengetahui dan mengaplikasikannya dalam kehidupan sehari-hari.

Piil pesenggiri sendiri sebagai identitas dan salah satu kearaifan lokal yang ada di daerah Lampung. Perwujudan piil pesenggiri, yaitu "Nemui Nyimah" (saling memuliakan), "Nengah Nyappur" (kerja keras/pantang mundur),"Sakai Sambaian” (menerima/lapang dada) dan "Juluk Adek" (pembelian gelar) (Fachrudin, 2009:7). Dengan kata lain, piil pesenggiri menjadi ciri sikap masyarakat Lampung yang memiliki kemauan tinggi dan tidak pantang mundur dari hal-hal yang diinginkan yang menyangkut memperjuangkan harga diri. Namun kenyataan yang ada di masyrakat Lampung, sedikit sekali yang menanamkan perwujudan piil pesenggiri di dalam kehidupan, bahkan terkadang mereka meninggalkan adat istiadat tersebut. Hal tersebut berdasarkan pengalaman peneliti di dalam kehidupan sehari-hari. Seperti dalam memuliakan tamu, dalam pengamatan peneliti, kini masyarakat Lampung sedikit sekali atau bahkan tidak lagi mengamalkan apa yang sudah menjadi landasan adat istiadat Lampung. Dalam piil pesenggiri seorang tamu dijadikan raja ketika berkunjung ke rumah, sehingga tamu tersebut dilayani, dimuliakan dan dikhidmati dengan santun serta diberikan suguhan kepada tamu tersebut, tapi hal yang demikian sedikit demi sedikit telah hilang dalam kehidupan masyarakat Lampung.

Fokus penelitian ini adalah "nilai-nilai kearifan lokal daerah Lampung dalam kumpulan lagu-lagu Lampung popular. Tujuan penelitian ini untuk "mendeskripsikan nilai-nilai kearifan lokal daerah Lampung dalam kumpulan lagu-lagu Lampung popular.

\section{Metode}

Penelitian ini dilakukan dengan menggunakan metode deskriptif. Hal ini sependapat dengan yang dikatakan oleh Basrowi dan Suwandi (2008:1) bahwa "penelitian kualitatif (qualitative research) adalah jenis penelitian 
yang menghasilkan penemuan-penemuan yang tidak dicapai dengan menggunakan prosedur-prosedur statistik atau dengan cara kuantifikasi lainnya".

Data dalam penelitian ini bersumber dari 10 lagu-lagu Lampung popular, yaitu Tanah Lado, Cangget Agung, Tepui-Tepui, Punyandangan, Mulei Menghanai, Mulang Tiyuh, Jama-Jama, Ito-Ito Menganai, Manjau Dimulei, dan Mak Lopo.

Dengan langkah-langkah pengumpulan data dilakukan sebagai berikut.

1. Mendengarkan kumpulan lagu-lagu Lampung populer.

2. Menyalin lagu-lagu tersebut ke dalam bentuk tulisan.

Adapun prosesnya, yaitu peneliti menyalin lagu-lagu Lampung tersebut di kartu data dengan melihat teks di bawah video cakram padat tersebut. Tulisan itu sangat jelas, sehingga memudahkan peneliti untuk menyalin teks tersebut. Lirik yang ada di teks pun sesuai dengan pengucapan vokal penyanyi, setelah peneliti mengamati dengan seksama pergerakan mulut dan artikulasi dari penyanyi.

3. Membaca lagu (syair) secara berulang-ulang, secara cermat untuk memahami hal-hal yang berkaitan dengan masalah yang akan dikaji.

4. Menandai hal-hal yang berkaitan dengan nilai-nilai budaya Lampung dalam kumpulan lagu-lagu Lampung populer.

5. Mencatat nilai-nilai budaya Lampung yang terdapat dalam kumpulan lagu-lagu Lampung popular di kartu data.

Di bawah ini langkah-langkah yang ditempuh untuk menganalisis data adalah sebagai berikut:

1. menentukan nilai-nilai budaya Lampung dalam kumpulan lagulagu Lampung populer,

2. mengelompokkan nilai-nilai budaya Lampung yang terdapat dalam kumpulan lagu-lagu Lampung populer,

\section{Hasil dan pembahasan}

\section{Hasil}

\section{Nemui yyimah}

Nemui nyimah terdiri atas "nemui" dan "nyimah". Kata Nemui berasal dari kata temui yang berarti tamu. Istilah tamu sangat erat dengan kegiatan saling memuliakan, saling hormat menghormati. Artinya, eksistensi manusia ditawali dari mampu menghargai orang lain, dan dihargai oleh orang lain. 
Adapun lagu yang memiliki nilai kearifan lokal berupa nemui nyimah adalah Tanah Lado (tanah lada) cipta Fath Syahbudin. Lagu "Tanah Lado" ciptaan Fath Syahbudin yang dinyanyikan oleh Muslih Harni terdiri dari empat bait tujuh belas larik. Bait pertama terdiri dari empat larik, bait kedua terdiri dari empat larik, bait ketiga terdiri dari empat larik, dan bait keempat terdiri dari lima larik. Lagu ini dianalisis dengan terlebih dahulu memerhatikan judul lagu tersebut.

Judul adalah indek bagi teks, karena merupakan nama teks bersangkutan. Judul biasanya menceritakan keseluruhan makna atau identitas terhadap sebuah lagu. Aktivitas memahami judul kemungkinan akan mendapatkan makna dari sebuah lagu. Lagu yang berjudul "Tanah Lado" memiliki arti tanah lada. Dari judul tersebut tersirat makna bahwa Lampung merupakan bumi yang masyarakatnya mayoritas berkebun, yang penghasilannya adalah lada. Di bawah ini salah satu kutipan yang terdapat nilai nemui nyimah. berikut:

Bait kedua lagu "Tanoh Lado" ciptaan Fath Syahbudin sebagai

\section{bumiku tanoh lampung ku lawi panjak wa wah di nusantara tani tu kun sangon jak jebi tanoh lampung ku tanoh lada}

\author{
'bumiku tanah lampungku sayang' \\ 'nampak jelas di nusantara' \\ 'bertani berkebun memang dari dulu' \\ 'tanah lampungku tanah lada'
}

Kutipan di atas menggambarkan tokoh aku yang mencintai dan menyayangi tanah kelahirannya, yaitu Lampung. Sikap tokoh tersebut menunjukkan usaha untuk selalu mencintai dan menyayangi tanah kelahirannya serta bangga menjadi pribumi tanah Lampung. Hal ini sesuai dengan esensi dari mampu menghargai dan dihargai.

\section{Nengah nyappur}

Pandai bergaul merupakan terjemahan dari nengah nyappur. Ada beberapa arti kata nengah, yaitu kerja keras, terampil, pilih tanding atau persaingan (Fachrudin, 2009:8).

Adapun lagu yang memiliki nilai kearifan lokal berupa nemui nyimah adalah Cangget Agung, Tanah Lado, Tepui-Tepui, Punyandangan, Mulei Meghanai, Mulang Tiyuh, Jama-Jama, Ito-Ito Menganai, dan Manjau Dimulei.

Di bawah ini salah satu kutipan lagu yang terdapat nilai nengah nyappur pada lagu Mulei Meghanai.

$\begin{array}{ll}\text { tanow ghadu waktunow } & \text { 'sekarang sudah waktunya' } \\ \text { segalo gham jejamo } & \text { 'semua kita bersama' } \\ \text { lestarikan budayo } & \text { 'lestarikan Budaya' } \\ \text { di tanah lampung ejo } & \text { 'di tanah lampung ini' }\end{array}$

Kutipan di atas menceritakan tentang keadaan yang ada di dalam diri si tokoh. Si tokoh digambarkan dalam bait pertama mengajak untuk bersama melestarikan budaya di tanah Lampung. 
Berdasarkan analisis yang telah diuraikan, peneliti menyimpulkan bahwa pada lagu "Mulei Meghanai" ini memiliki unsur nengah nyappur. Di dalam lagu ini si tokoh berusaha mengajak kepada generasi muda (bujang gadis) untuk memanfaatkan waktu dan bekerja sama dalam melestarikan budaya Lampung demi nusa dan bangsa.

\section{Sakai sambaian}

Sakai sambaian terdiri atas dua kata, yaitu kata sakai yang berasal dari kata akai yang berarti terbuka dan kata sambai atau sumbai yang berarti 'melihat', 'amati' dan 'pelihara'. Keterbukaan sikap merupakan prilaku yang diharapkan dapat melakukan berbagai perbaikan.

Adapun lagu yang memiliki nilai kearifan lokal berupa sakai sambaian adalah "Mak Lopo". Lagu ini berjudul "Mak Lopo" yang memiliki arti tidak lupa. Maksud dari judul lagu ini adalah meskipun si tokoh tidak lagi bersama dengan kekasihnya, tapi si tokoh tidak pernah melupakan segala jasa ketika bersama-sama.

Nilai sakai sambaian pada lagu ini terdapat pada bait ketiga. Kutipan bait tersebut adalah sebagai berikut:

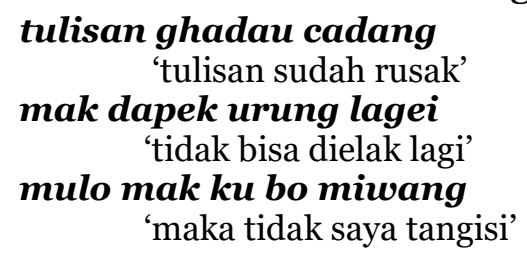

Kutipan di atas menggambarkan bahwa si tokoh menerima takdir yang telah ditetapkan oleh Tuhan yang tidak dapat dielak lagi. Oleh sebab itu, si tokoh menerima dengan sikap terbuka dan lapang dada dengan keadaan yang ada, serta tidak pernah menyesali dan menangisi keadaan yang sudah terjadi karena tidak ada gunanya menangisi dan menyesali keadaan yang telah terjadi

\section{Juluk adek}

Pemahaman juluk adek bagi masyarakat Lampung adalah sebagai pemasangan nama baru. Juluk adalah nama lain yang diberikan secara formal (dengan upacara) kepada seorang anak atau remaja yang dapat menyusun cita-citanya sebagai rencana hidupnya, dan adek atau adok, yaitu nama lain yang diberikan kepada seseorang dengan upacara kebesaran (cakak pepadun) yang diselenggarakan secara terang-terangan karena yang bersangkutan mampu meraih cita-citanya itu.

Lagu yang memiliki nilai kearifan lokal berupa Juluk adek di dalam penelitian ini hanya ada satu lagu. Lagu itu adalah "Cangget Agung" yang diciptakan oleh Syaiful Anwar. Pada lagu ini yang pertama dianalisis 
adalah judul lagu, yaitu "Cangget Agung" yang berarti sebuah tarian adat Lampung pada saat upacara pelamaran/pernikahan gadis di Lampung.

Nilai juluk adek pada lagu ini terdapat pada bait pertama. Kutipan bait tersebut adalah sebagai berikut:

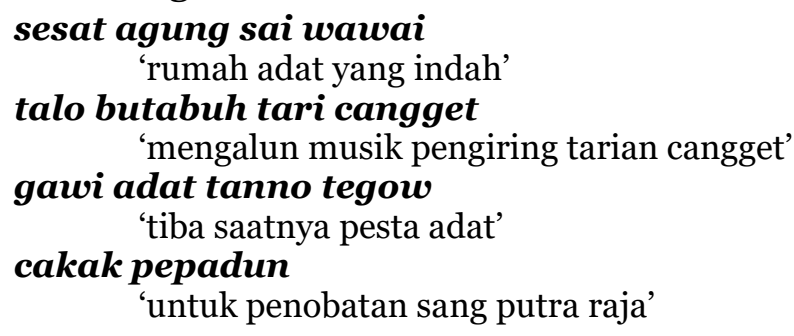

Kutipan di atas mengggambarkan dari adat budaya Lampung, yaitu seseorang dilantik menjadi tuan raja. Jika sudah sampai tahap itu, berhak dikukuhkan gelar tersebut dengan mengadakan upacara puncak yang dikenal dengan sebutan cakak pepaduan (berpesta adat besar untuk naik tahta tertinggi di dalam adat ke punyimbang atau sebagai suntun). Berdasarkan analisis yang telah dilakukan di atas, judul tersebut memiliki unsur budaya Lampung, yakni "juluk adek".

\section{Pembahasan}

Nilai-nilai piil pesenggiri yang ada di dalam kumpulan lagu-lagu Lampung populer yang telah dianalisis merupakan suatu hal yang seharusnya dianut dan diterapkan oleh masyarakat Lampung dalam kehidupan sehari-hari. Kenyataan yang ada adalah masyarakat Lampung sedikit sekali mengamalkan nila-nilai yang sudah menjadi adat dan kebudayaan mereka, terutama pada kalangan remaja. Hal ini dapat dilihat dari kehidupan masyarakat Lampung khususnya diperkotaan yang sedikit sekali mengadakan adat pernikahan secara utuh, mengadakan makan bersama jika tamu berkunjung ke rumah, individualistis dan bahkan tidak saling memaafkan jika ada kesalahan yang mengakibatkan pertengkaran sesama suku Lampung. Hal demikian diketahui berdasarkan pengalaman peneliti setelah mengadakan observasi secara langsung. Oleh karena itu, penelitian ini juga menyadarkan masyarakat Lampung untuk membangun kembali adat dan budaya Lampung secara utuh yang selama ini telah ditinggalkan. Sebagaimana telah diketahui bahwa masyarakat Lampung memiliki sikap terbuka dan kerja keras demi menggapai cita-cita untuk kehidupan di masa depan yang lebih baik. Konsep ini sejalan dengan nilai piil pesenggiri yang lebih dominan pada penelitian ini, yakni nengah nyappur yang berarti sikap kerja keras, tidak menyerah serta tangguh terhadap sesuatu. 


\section{Simpulan}

Hasil analisis yang telah dilakukan pada kumpulan lagu-lagu Lampung populer terdapat sepuluh lagu yang memiliki nilai-nilai budaya Lampung. Satu lagu yang memiliki nilai nemui nyimah, yaitu Tanah Lado. Delapam lagu yang memiliki nilai nengah nyappur, yaitu; Tanah Lado, Cangget Agung, Tepui-Tepui, Punyandangan, Mulei Meghanai, Mulang Tiyuh, Jama-Jama, Ito-Ito Menganai, dan Manjau Dimulei. Satu lagu yang memiliki nilai sakai sambaian, yaitu Mak lopo, serta satu lagu yang memiliki nilai juluk adek, yaitu cangget agung.

Berdasarkan analisis yang dilakukan pada kumpulan lagu-lagu Lampung populer yang memiliki nilia-nilai budaya Lampung dan telah dijabarkan pada BAB IV, sehingga mendapat kesimpulan bahwa kumpulan lagu-lagu Lampung populer memiliki nilai-nilai budaya Lampung. Nilanilai budaya Lampung dalam kumpulan lagu-lagu Lampung populer yaitu piil pesenggiri terdiri dari: a) nemui nyimah, b) nengah nyappur, c) sakai sambaian, dan d) juluk adek.

\section{Daftar rujukan}

Basrowi dan Suwandi. 2008. Memahami penelitian kualitatif. Jakarta: Rineka Cipta.

Fachrudin. 2009. Menggali kearifan lokal daerah Lampung untuk penanggulangan problema sosial. Bandar Lampung: Dinas Sosial Provinsi Lampung.

Halim, Andreas. 2003. Kamus saku 25 milyard. Surabaya: Fajar Mulya.

Ningsih, D. R., \& Irawan, W. D. (2018). Kajian struktural sastra lisan pepaccur masyarakat lampung pepadun dalam prosesi pengambilan gelar adat. Edukasi Lingua Sastra, 16(2), 59-67. 